Cahiers $d u$ MONDE RUSSE

\section{Cahiers du monde russe}

Russie - Empire russe - Union soviétique et États indépendants

$52 / 2-3 \mid 2011$

L'URSS et la Seconde Guerre mondiale

\title{
Caught between war repressions and party purge
}

The loyalty of Kalinin Party members put to the test of the Second World War

Pris entre les répressions de la guerre et les purges du parti. La loyauté des membres du parti de Kalin in mise à l'épreuve de la Secon de Guerre mondiale

\section{Vanessa Voisin}

\section{OpenEdition}

\section{Journals}

Electronic version

URL: https://journals.openedition.org/monderusse/9338

DOI: 10.4000/monderusse.9338

ISSN: $1777-5388$

\section{Publisher}

Éditions de l'EHESS

\section{Printed version}

Date of publication: 15 November 2011

Number of pages: $341-371$

ISBN: 978-2-7132-2352-5

ISSN: $1252-6576$

\section{Electronic reference}

Vanessa Voisin, "Caught between war repressions and party purge", Cahiers du monde russe [Online], 52/2-3 | 2011, Online since 12 September 2014, connection on 04 September 2022. URL: http:// journals.openedition.org/monderusse/9338 ; DOl: https://doi.org/10.4000/monderusse.9338

This text was automatically generated on 4 September 2022.

All rights reserved 


\title{
Caught between war repressions and party purge
}

The loyalty of Kalinin Party members put to the test of the Second World War

\author{
Pris entre les répressions de la guerre et les purges du parti. La loyautédes \\ membres du parti de Kalin in mise à l'épreuve de la Secon de Guerre mondiale
}

Vanessa Voisin

1 "The institutions of purge and verification were born with the Bolshevik Party itself. The quest for purity among the revolutionaries' ranks was at the heart of the MarxistLeninist ethos." Indeed, from its origins, the Bolshevik Party underwent regular purges aiming at expelling socially alien (admitted on a fake autobiography), incompetent or undisciplined members, or those who strayed from the general line. Despite the calming down of Party life after the mass expulsions of the Great Purges, the new Statute of 1939 presented the purge as a basic principle of Party management. ${ }^{2}$ So the Party cleansing in the aftermath of the liberation from Nazi rule suited both Party routine as well as extraordinary circumstances. The discovery of numerous acts of collaboration with the enemy, including those committed by Party activists or leaders, strengthened the conviction of the existence of a "fifth column" in the country, and even inside the organs of power. ${ }^{3}$ But the context of war tended to increase the urgency and the complexity of the purge. On one hand, there was a lack of activists, many Party members being mobilized in the army while others had died during the occupation, but on the other hand it was essential to purify the organization from those members who discredited themselves and the Party with the population. More profoundly, the Second World War changed the criteria that defined the good communist, completing a shift initiated in the 1930s from genealogical criteria of appraising a communist (social origin, political past...) to criteria focused on the inner "self" of the communist. ${ }^{4}$ As class war was declared over in the mid-1930s, the enemy could no longer be unmasked through careful inquiry on his social origins and political past. From now on, the remains of the bourgeois past had to be tracked down in the conscience of individuals, even in the case of communists. 
2 This article will try to seize the role of the war in this process. Indeed, how a communist reacted to the threats hanging over the Bolshevik project was the best test to measure his understanding of the social and political mission of the Party. The war was the ultimate test and for years after the conflict, the criteria of censure and expulsion would be closely linked to their own individual attitude during the war. Citizens from the liberated areas were subjected to latent suspicion, but the highest pressure was put on the supervision structures from which the State especially expected loyalty. It is important to point out that, though they often intersected and overlapped, the purge of the Party and the purge of the economic and State administrations did not always follow the same logic. ${ }^{5}$ Moreover, in my opinion it is a mistake to draw general conclusions about the purge of the Party using examples concerning the "cadres" 6 First, the cadres were not always Party members, especially at the lowest levels, so their purge must be studied separately. Second, cadres underwent an often smoother purge than the purge of the organizations in general, obviously because officials and managers were necessary to rebuild the administration and the economy, at least until demobilized soldiers came back from the front starting from the summer and autumn of 1945. To lighten the text, I will limit the analysis to the case of Party members, while trying to determine whether the sanction differed according to the position they occupied before the invasion.

3 Contrary to the rich Western historiography on administrative and professional purges of collaborators after the liberation, the study of the Party purge of the war years remains underdeveloped, and the publications dating from Soviet times do not even mention the purge.7 Amir Weiner's pioneer work, published in 2001, paved the way for further research with its major conclusions about the role of the second world conflict in redefining Soviet identities. ${ }^{8}$ Other local or national studies about the aftermath of liberation or/and the transition from war to peace touched on to this topic, such as Nathalie Moine's rich study of the Slantsy district (province of Leningrad), Jeffrey Jones' work on the "reconstruction" of Rostov-on-the-Don or the works dealing with the process of sovietization in the Baltic states. ${ }^{9}$ Lastly, Rebecca Manley's recent book on the evacuation and re-evacuation has brought up central questions about the confrontation of conflicting war experiences, while providing a solid basis for understanding the circumstances, often chaotic, of the departure of local authorities on the eve of invasion. 10

4 The present paper will try to give some insights into the process of redefining Party loyalty and Party ethos through the ordeal of the war. The case study at hand, the province of Kalinin, allows one to trace the very beginning of the purge in January 1942 and to follow its evolution through the different stages of the war. The corpus consists of reports from and to the Organization and Instruction Department of the Central Committee (Orginstruktotdel TsK) which give an overview of the purging process in the Soviet Union as well as of Moscow's criticism and orders. ${ }^{11}$ Provincial archives provide invaluable material on concrete implementation of the purge in the field, week after week, and on diverging understandings of the meaning of the process at local and regional levels. ${ }^{12}$ Finally, the analysis of a delimited number of cases allows an evaluation of the respective weight of the various criteria used to determine whether the communist should be reinstated or expelled from the Party. 


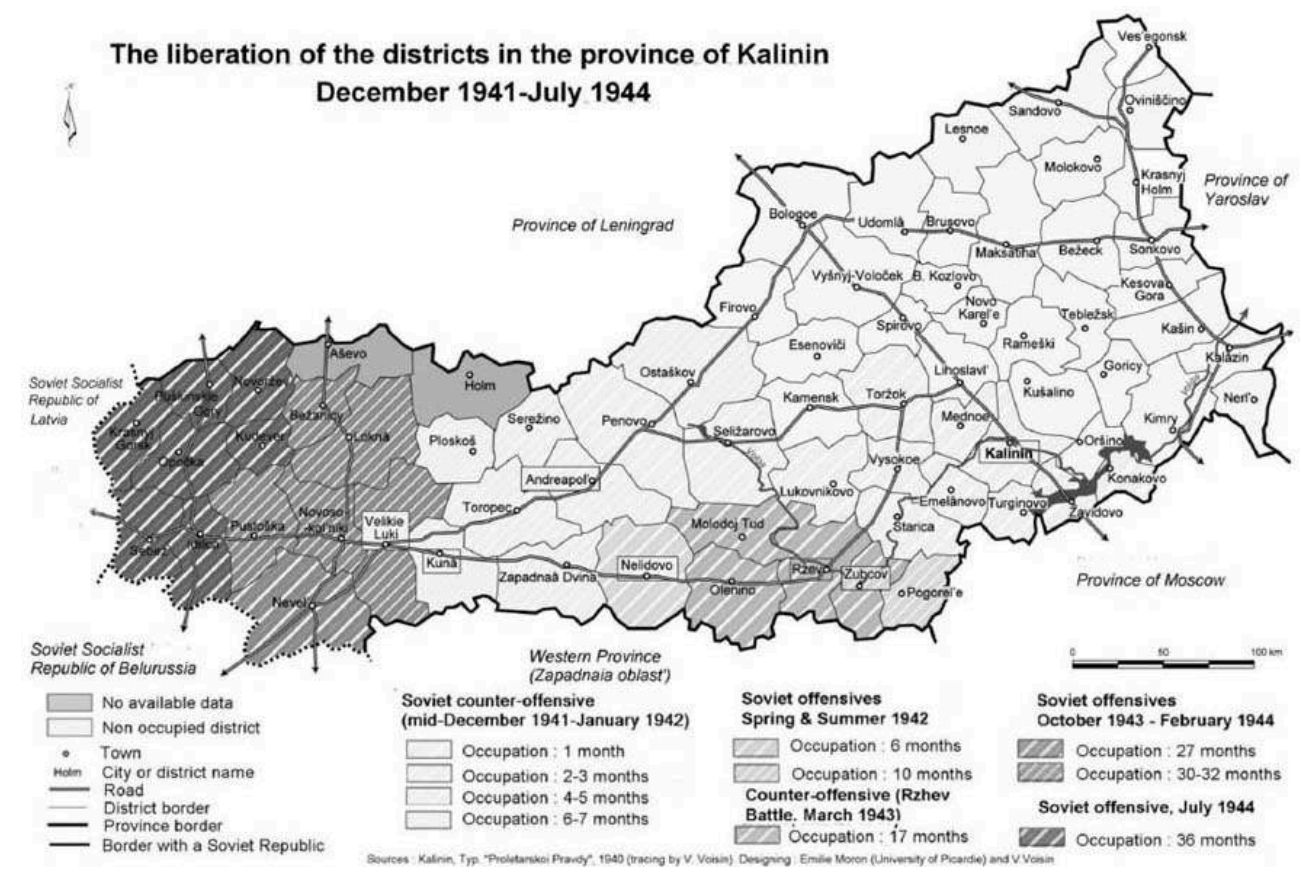

5 First, I shall briefly present the general context of the purge in the province of Kalinin and of its launching. Then I shall study the conflicting understandings of the purge by the different levels of power in the Party. Last, I shall discuss the meaning of the charges held against the expelled communists, keeping in mind the European context of administrative sanction of collaborators.

\section{Launching the purge: an urgent and crucial question}

\section{A miniature USSR}

The province of Kalinin borders the provinces of Leningrad in the North and of Moscow in the South, the Latvian and Belorussian republics in the West and the province of Yaroslav in the East (see map). What makes it of interest to the study is that the districts of the region suffered different fates during the war: the German troops never invaded the north-eastern part of the Kalinin province, while the districts surrounding the provincial center underwent a short-time occupation and the western and southern ones were submitted to the enemy for several months, and for some of them, for years (see map). The first districts to fall into enemy hands, at the beginning of July 1941, were the western ones; they remained under occupation until the end of 1943 or the year 1944. The others were mainly invaded in the autumn of 1941, during the "Operation Typhoon" launched by the Germans on October 2, 1941. While Kalinin was occupied, from midOctober to mid-December 1941, the provincial authorities were evacuated to Kashin, the administrative center of a north-eastern district, while the industrial and agricultural equipment was sent far in the rear when the time left made it possible. From Kashin, the provincial Party committee (Obkom) and the regional head of NKVD (UNKVD) organized the underground resistance in occupied territory and prepared embryos of new authorities - especially the district Party and State committees and the local NKVD organs - in anticipation of the liberation of the invaded districts. 
7 The province was a sort of miniature USSR at war: in the rear, it had never been invaded and provided relatively safe conditions (although it did suffer strong bomb attacks) to organize and lead the fight further west, while a strip of districts remained under threat and constituted an intermediary space between the front and the rear. Lastly, the occupied territory was progressively freed, first becoming an undefined zone between the front and the rear, and then a rear: the priorities in these territories depended on their closeness to the front and their vulnerability. The most striking feature is that, despite its proximity to Moscow (less than 200 kilometers), the province was not completely liberated until July 1944.

8 The first wave of liberation took place in December 1941-January 1942, during the Soviet counter-offensive of the "Battle of Moscow." The German invader left twenty districts and four towns (Kalinin, Velikie Luki, Andreapol', Kunia), but still held the southern and western parts of the region. The first one was partly freed in the summer of 1942, and then completely in March 1943, when the Wehrmacht abandoned Rzhev for the third and last time. The twelve western districts still occupied in 1943 were not retaken by the Red Army until 1944, during the two offensives of February and July. Soon after, many of these districts were cut off from the Kalinin province to be included in the newly formed provinces of Velikie Luki and Pskov. ${ }^{13}$

\section{A Moscow top priority: purifying the Party}

9 As early as January 4, 1942, the Party cell of the Kalinin Proletarskii district discussed the question of the communists who had remained on occupied territory: most of the speakers had just come back from the rural neighboring districts where they had fled, and they inclined to pronounce systematic expulsion..$^{14}$ In other liberated provinces, voices also expressed indignation about the scale of communist collaboration with the enemy, and addressed the Party's Central Committee to ask for the harsh punishment of traitors. ${ }^{15}$ Indeed, the number of compromised communists filled the authorities with dismay, as witness the reports from Kalinin and Voronezh in early 1942, Rostov, Leningrad, Kabardino-Balkariia, Kursk, and Velikie Luki in 1943. ${ }^{16}$ Less than a month after Kalinin was freed from Nazi rule, an inspector from the Central Committee arrived there to evaluate the work of the authorities. He drew very stern conclusions about the Party's regional committee: the latter had not taken vigorous measures to foster material reconstruction, nor to develop active "political work" with the population of the freed territory. No instructions had been given to the district committees about the communists who remained in invaded areas, while in some neighborhoods, they represented more than half the number of Party members before the invasion. On January 11, 1942, the NKVD had already arrested 15 communists for active collaboration with the enemy. ${ }^{17}$

10 The local powers being overwhelmed by the material problems to solve, they did not give enough attention to the Party situation, and this negligence was common to many liberated areas. ${ }^{18}$ Therefore, Moscow decided to take things in hand. On January 17, 1942, Shamberg, head of the Organization and Instruction Department of the Party's Central Committee (Orginstruktotdel), sent a note to the three Central Committee secretaries who followed the implementation of the purge until the end: A. Andreev, G. Malenkov, A. Shcherbakov. ${ }^{19}$ He proposed a project for a Central Committee resolution dealing with administrative and Party purges. The quickness of the Center's reaction reveals the 
significance attached to the purge at the highest political level, an importance which found confirmation in the following months. In early February 1942, the delegate of the Party Control Committee (KPK) in Kalinin criticized the slow pace of the purge in the provincial capital and in the districts of Staritsa, Turginovo, Zavidovo. The Obkom bureau had to acknowledge its bad handling of the problem and to promise to give the necessary instructions. ${ }^{20}$ Thereafter, the Central Committee kept a close eye on the purge from beginning to end. In early March 1942, Shamberg informed the three secretaries that many Party committees had not been paying enough attention to the purge: in Orël, only 23 cases had been examined in the preceding month, and the situation was not better in Rostov. As a consequence, traitors still stood in the Party, and sometimes even held positions of power. Therefore, the Orginstruktotdel demanded regular accounts on this topic, ${ }^{21}$ which remained a Moscow top priority until the end, becoming "one of the most closely monitored purges in Soviet history." 22

\section{Implementing the purge}

11 I did not find any proof of Shamberg's project being ratified in the central or regional archives, but local reports suggest its main lines were adopted. As Shamberg proposed, local authorities organized a thorough registration of all Party members "in order to expel the people who did not honor the title of member of the Bolshevik Party during the fight against the fascist invaders." ${ }^{23}$ The registration was to be announced in the local press, and deadlines to be fixed: any Party member coming to the committee after the deadline would be expelled (third and fourth points of Shamberg's project). Another of Shamberg's suggestions seems to have been followed: the Party committees bureaus were entrusted with the task of examining the cases, in contradiction with the Statute of 1939, which defined the primary cells as the level of discussion of expulsion cases. A report dated August 1943 about the progress of the purge in Kabardino-Balkariia stated it unequivocally: the Elbrous local committee had made a mistake when it entrusted the primary cells with the purge, because "most of their members remained on occupied territory" and they reinstated a high number of communists who "had not deserved the trust of the Party." ${ }^{24}$ Besides, in the weeks and months immediately following the liberation, many cells had not yet been reconstituted.

12 The rules of the verification process worked toward reasserting the internal Party hierarchy. Any decision taken by the local committees had to be checked out and ratified by the provincial committee, which had to meet often (three to five times a month) to study communists' personal files..$^{25}$ The Party Control Committee kept a close eye on provincial purges, while the Central Committee sent delegates in the field. In Kalinin, the Central Committee's delegate attended seven sessions out of 47 in 1942. This tight supervision allowed the center to exert pressure on regional organizations, to convince them of the importance of the purge, and finally to impose a unique vision of the good communist at war. ${ }^{26}$

Despite these peculiarities, the purge followed the main principles of the previous purges since the mid-1930s: the examination of the personal files was to be strictly individual and based on an inquiry. ${ }^{27}$ It meant that Moscow rejected a treatment of the problem by categories, preferring to keep room for maneuver according to situations. That way, the war verification was part of the regular Party purges and did not seem to bear an extraordinary character. Concerning the beginning of the judicial repression, the 
authorities carefully avoided publicity over the process: the scale of collaboration from Party members was not a topic to be on display. Despite the fact that chief editors of the provincial newspaper, Proletarskaia Pravda, attended nearly all the sessions dealing with expulsions from the Party between 1942 and 1945, I found no mention of the purge in the local newspapers..$^{28}$ Only Partiinoe Stroitel'stvo, the central organ devoted to the Party life, briefly touched upon the subject in an article describing the restoration of Soviet power in liberated territory:

The Party organization and the raikomy [district Party committees] are carrying out a great cleansing work of Party ranks, expelling those who did not justify the noble title of communist, who stained the name of Bolshevik out of human weakness or cowardice. The underground committee expelled Vasin and Plosnin who were afraid of joining the partisan unit and fled away. Party organizations are closely and severely examining the behavior of each communist who remained on occupied territory by checking out their activities..$^{29}$

The methods of verification were not described in Shamberg's project, nor in any other text I found. Kalinin archives do not keep the complete stenogramme of the district or regional bureau sessions, making it impossible to know exactly how the facts were established, on which base the bureau made their decisions and how the discussions were organized. The archives only contain "explanations" written by verified communists, notes prepared by the local committees and inquiry reports from the NKVD, which informed the Party authorities of the arrest of a Party member. ${ }^{30}$ Some of these NKVD documents bear a manuscript note of a Party official, saying: "A decision was taken [date]." ${ }^{31}$ This state of the sources does not allow us to draw any conclusion about the temporal and causal link between Party inquiry and censure and police and judicial procedures. Since December 1938, the Party secretary's authorization had been needed for the police or prosecutor to put a communist under arrest..$^{32}$ But in the files I saw, the NKVD informed the Party committee of an arrest after the fact, not waiting for any kind of approval. We can assume that the purge of collaborators was a matter of great urgency for the police - the war was still raging and the front not far away - and that in the eyes of the NKVD the nature of the crime did not allow any kind of postponement for the arrest.

15 After the district committee had made a decision, the member's file was to be transmitted to the Obkom where the conclusions were verified and ratified, or corrected. In Kalinin, the high number of decisions taken at each session of the regional bureau in 1942 suggests a hasty verification of the raikomy's decisions. As for the rights of the checked communists, they remained unclear until November 1943, when the Central Committee adopted a decision stating that the expelled members could attend the Obkom bureau session where their case was examined..$^{33}$ The expelled communists could also appeal against the decision to higher Party organs: the regional committee, the Central Committee, the Party Control Committee. Of course, if they were already under arrest, there was a problematic infraction to Party rules.

What happened to the communists during the verification process? Sometimes it took months, and in the province of Kalinin no document casts light on their position in relation to the Party cell during this time. It seems that, at first, Moscow let the local powers define their policy with regards to these members: in his March 1942 report about the purge in Rostov, Shamberg underlined that the provincial committee decided to ban them from Party meetings, because they tried to excuse and justify their shameful behavior before their comrades. ${ }^{34}$ Anyhow, in Kalinin, the professional consequences of 
the purge were important. The decisions of the regional bureau indicate the position occupied before and after the occupation and clearly show a drop in status for nearly all the compromised low-level officials, whether they had been arrested by the NKVD or not. For example, when the cases of I. Boikov and V. Tsvetkov were verified by the obkom, both had already lost their jobs as chairman of a rural soviet for the first one, and chairman of a collective farm for the other. Boikov was expelled for not joining the partisan unit and afterwards registering with the enemy police; Tsvetkov for serving as an interpreter for the occupying troops. Surprisingly, the Party decisions did not mention an arrest by the NKVD, ${ }^{35}$ contrary to many other cases examined in 1942 and, at a lower level, in $1943 .{ }^{36} \mathrm{All}$ in all, for the three months I picked randomly and studied in detail - June and October 1942, June 1943 -, the degraded or dismissed officials who were still at large made up $18 \%$ of the cases. The communists who kept their prewar job or found an equivalent one - expelled from the Party or not -, represented a similar proportion, $20 \%$. Another quarter was made up of unemployed communists. There were also slight drops in status, for example, skilled workers losing their position and finding only unspecialized jobs; but these cases were balanced by the number of promotions. ${ }^{37}$ Thus, if some communists who underwent the occupation went on without serious professional complications after the liberation, several even being promoted, $61 \%$ of the studied sample had to face prosecution, degradation or unemployment. Taking into account the general lack of specialists and managers during the war, the drops in status were unlikely to result from accident; most probably, they aimed to put aside suspicious or shameful members.

17 As a time interval of an average of two months separated the decision of the district committee from the ratification by the obkom, judiciary repression and professional degradation usually preceded the Party's final word. Despite that advantage - the Obkom had more information at their disposal - the various visions of the purge at different Party levels needed time to adjust to one another.

\section{The chronology of the purge in Kalinin}

After the first Central Committee warning in early 1942, the purge of Kalinin's organization accelerated. According to the head of the provincial Orginstruktotdel, on March 3, 1942, the district committees had already ruled on $51 \%$ of the 1,150 files registered at that time. ${ }^{38}$ During the same month, the Obkom took the pace and began to meet four to five times a month ${ }^{39}$ examining over a hundred cases during some sessions, as on May 27 and June 10, 1942. Table 1 clearly shows that the bulk of the files was treated in 1942, after the winter and the summer Soviet counteroffensives, followed by smaller successes in the fall. Later, the share of the war purge in the whole number of communists' files examined by the provincial committee regularly diminished: from $70 \%$ in 1942 to $45 \%$ in $1943,42 \%$ in 1944 and $30.5 \%$ in 1945 . The relatively high figures of 1943 and 1944 correspond to new offensives by the Red Army and to the (re-) examination of cases of the previous year. ${ }^{40}$ In 1945 and 1946, the Obkom treated a remainder of cases. 
Table 1. The purge progress in the province of Kalinin, 1942-1950

\begin{tabular}{|l|c|c|c|c|c|}
\hline & 1942 & 1943 & 1944 & 1945 & $1942-45$ \\
\hline $\begin{array}{l}\text { Cases examined by the provincial } \\
\text { Party committee }\end{array}$ & 2699 & 784 & 1317 & 753 & 5553 \\
\hline $\begin{array}{l}\text { Cases related to attitude during } \\
\text { the occupation }\end{array}$ & $\begin{array}{c}1891 \\
(70.1 \%)\end{array}$ & $\begin{array}{c}351 \\
(44.8 \%)\end{array}$ & $\begin{array}{c}553 \\
(42 \%)\end{array}$ & $\begin{array}{c}229 \\
(30.4 \%)\end{array}$ & $\begin{array}{c}3024 \\
(54.5 \%)\end{array}$ \\
\hline $\begin{array}{l}\text { Percentage in relation to the total } \\
\text { number of cases related to attitude } \\
\text { during the occupation (1942-1950) }\end{array}$ & $61.4 \%$ & $11.4 \%$ & $17.9 \%$ & $7.4 \%$ & $98.1 \%$ \\
\hline
\end{tabular}

Sources: RGASPI, f.17, op.43, d.743-754; op.44, d.547-554; op.45, d.733-739; TTsDNI, f.147, op.4, d. 25-26; f.147, op.4, d.1117-1114; f.147, op.4, d.1521-1522; f.147, op.4, d.1947-1948.

In Kalinin, the purge began at a frantic pace during the first year (1942) but quickly slowed down. It is difficult to compare with other Russian provinces since the examples I have found present a different chronology of the liberation. In Rostov province, for example, the liberation also started in 1942, but the regional capital was retaken by the enemy the same year. This probably explains, at least partly, why only $28 \%$ of the Rostov war purge cases were ruled on during the first year (1942), while $61.4 \%$ of the 3,081 Kalinin ones were decided during the same period. Nevertheless, in Rostov purification of the Party from traitors, cowards and shameful members was over in late $1945^{41}$; in Kalinin, where the number of communists who remained on invaded territory was three times smaller, two percent of the identified cases still awaited decision.

The specific chronology of the purge in the province of Kalinin probably finds an explanation in the Obkom's reaction to the Central Committee warning of February 1942. Thereafter, First Secretary I.P. Boitsov closely supervised the progress of the cleansing in the newly liberated areas. Three times in 1942, he reprimanded local committees for being slow or negligent in relation to the purge, and he made his reproaches public to the other raikomy. ${ }^{42}$ Meanwhile, the local Party committees regularly sent him reports on the progress of the purge..$^{43}$ The Obkom's control was obviously loosened in 1943, as the supervision of the Central Committee through its delegates. This loosening probably explains the critical fall of the number of war purge cases that were ruled on this year (only $11.4 \%$ of the whole number of cases for 1942-1950), whereas this was a liberation year (see map).

But the huge share of the year 1942 in the cleansing process does not mean that the local powers quickly understood what was expected from them. In fact, they constantly groped around the right approach as they had not received clear-cut instructions about the criteria and methods they should use. ${ }^{44}$ However, the regional committee kept a leg up in comparison with the district committees, because it was the first to receive the blame and advice from the Central Committee.

\section{Diverging visions of the purge}

Shamberg's project put the purge under the tight control of the Central Committee's Secretariat. Indeed, its Orginstruktotdel supervised local action by analyzing the reports addressed by the regional powers and by sending delegates to the provinces. The latter not only checked the progress of the purge, but also the decisions themselves and the supervision exerted by the Obkom. Their stern criticism was always followed by advice. 
However, quite surprisingly, the areas liberated at a later period of the war did not seem to benefit from the experience of earlier cases; in Vinnitsa, for example, the purge started in a highly improvised manner and aroused exactly the same reproaches from Moscow as the Kalinin or Voronezh purges two years before. ${ }^{45}$ Thus, despite the great emphasis placed on the purge by the central authorities, the passing on of the information and advice was not always foreseen or effectively done.

Contrary to other provincial secretaries, regularly scolded by Moscow for their bad supervising, ${ }^{46}$ Boitsov was only blamed at the beginning of the purge, in 1942, and after the end of the war in November $1945 .{ }^{47}$ The discretion of the Central Committee suggests they were quite satisfied about the way the Kalinin authorities were handling the purge. But in the field, the obkom had to review many decisions taken by the district committees (see table 2).

Table 2. Obkom examination of decisions taken by the district committees

\begin{tabular}{|l|r|r|r|r|r|r|r|r|}
\hline \multicolumn{1}{|c|}{ Obkom final decisions } & \multicolumn{2}{|c|}{1942} & \multicolumn{2}{c|}{1943} & \multicolumn{2}{c|}{1944} & \multicolumn{2}{c|}{1945} \\
\hline & & $n=1891$ & & $n=351$ & & $n=553$ & & $n=229$ \\
\hline - Expulsions confirmed & 1204 & $63.7 \%$ & 316 & $90 \%$ & 513 & $92.8 \%$ & 219 & $95.6 \%$ \\
\hline $\begin{array}{l}\text { - Replacement of a destructed } \\
\text { membership card }\end{array}$ & 544 & $28.8 \%$ & 13 & $3.7 \%$ & 1 & $0.2 \%$ & 1 & $0.4 \%$ \\
\hline - Expulsions cancelled & 120 & $6.3 \%$ & 20 & $5.7 \%$ & 3 & $0.5 \%$ & 2 & $0.9 \%$ \\
\hline - Reinstatements cancelled & 37 & $2 \%$ & 3 & $0.9 \%$ & 25 & $4.5 \%$ & & $0 \%$ \\
\hline $\begin{array}{l}\text { - Removal of a blame inflicted } \\
\text { during the purge }\end{array}$ & & & & & 10 & $1.8 \%$ & 8 & $3.5 \%$ \\
\hline $\begin{array}{l}\text { - Reinstatement in the Party, } \\
\text { after an expulsion during } \\
\text { the purge }\end{array}$ & & & & & 1 & $0.2 \%$ & & \\
\hline
\end{tabular}

Source: RGASPI, f.17, op.43, d.743-754; op.44, d.547-554; op.45, d.733-739; TTsDNI, f.147, op.4, d. 25-26; f.147, op.4, d.1111-1114; f.147, op.4, d.1521-1522; f.147, op.4, d. 1947-1948. Comment: in several cases, the replacement of the membership card is associated with the cancellation of the expulsion, which explains a total exceeding $100 \%$.

During the first year, the provincial committee cancelled more expulsions (6.3\%) than reinstatements (3\%); moreover, they pronounced nearly $30 \%$ decisions of issuing new membership cards to the communists who had lost or destroyed their old one since the Nazi invasion. One of the causes - probably the main one - of this relative leniency lay in the slapdash job of the raikomy which expelled communists without sufficiently investigating their behavior during the occupation. In the examples provided in the Party Control Committee's reports, further inquiry revealed that the expelled members actually displayed patriotism..$^{48}$ Thus, the Kalinin city committee reinstated Solov'eva, expelled by the Central district committee, because investigations found that she had hidden and taken care of a wounded Soviet soldier lying in the street; the Obkom approved and ratified this decision..$^{49}$ More often, the cancellation of the decisions of the raikomy resulted from the consideration of some circumstances explaining the failure of evacuation and also of certain general criteria of behavior.

As for the cancellations of reinstatements, the explanation resides in the leniency of some local committees which took the justifications of verified communists as truth 
instead of making their own inquiry.$^{50}$ Investigations on the activities of the communists who remained in occupied territory absorbed a huge amount of time, and the raikomy seemed to have given the priority to other tasks. Moreover, their proximity to the field realities probably made them more sensitive to the locals' material problems. The provincial committee took care in making it clear that Moscow attached great importance to the purge, and cancelled all the local rulings based on generic and vague phrases, such as "voluntarily remained in occupied territory," "destroyed his membership card" or "did not work for the Germans" (for reinstatements). In 1943, the Obkom approved a higher rate of local decisions (90\%), even if they still cancelled six percent of the total. The next year, the rate was reversed; only $0.5 \%$ of the expulsions were cancelled against $4.5 \%$ of the reinstatements. No major event accounts for this change; I shall assume that the district committees finally assimilated the expectations of their hierarchy. In 1945, convergence between regional and local visions was almost perfect: $96 \%$ of the decisions were ratified.

Initially, the reproaches addressed by the Kalinin Obkom to their subordinates found their counterpart in the other liberated provinces. For instance, the report that the head of the Voronezh Orginstruktotdel sent to Shamberg in March 1942 bemoaned the massive expulsions pronounced by the district committees. They blurred and harmed the "explanation work" that the purge was expected to generate inside the Party. ${ }^{51}$ Thus, at the highest levels of Party power, it was clear that the process did not only pursue concrete purifying goals, but also bore an essential normative dimension. Indeed, the Central Committee was well informed of the many tasks that the local Party committee had to cope with in the aftermath of a ravaging occupation, when the government demanded huge human and material participation from the provinces to sustain the war effort. Moreover, the NKVD quickly told its hierarchy as well as the Party committees that the most compromised collaborators had fled westwards with the Wehrmacht. So the meticulous verification of all the local communists did not only aim at discovering dangerous traitors; there was a symbolic purpose of the purge, which only the Party was empowered to define and display.

\title{
Purifying the vanguard of society, redefining values and norms of behavior
}

\author{
Each Party member has begun to feel that he is a \\ fully valued unit, who is tied to the general \\ collective of the Party, and who is responsible for \\ the whole. ${ }^{52}$
}

In 1939, Zhdanov congratulated himself on the collective spirit of the Party, which had just been through terrible ordeals in the previous years. In Kalinin, the 1935 expulsions decided during the replacement of the membership cards had provoked a first significant fall of the number of activists. Then, the Great Purges struck and cost the Party organization 1,000 more members (see table 3). After undesirables had been expelled, the recruitment campaign of 1939-1941 led to a twofold increase of Party numbers. The war was to shake a renewed and frail organization. 
Table 3. The number of Kalinin activists, 1935-1941

\begin{tabular}{|l|l|}
\hline 1935 & 27,411 \\
\hline 1936 & 24,483 \\
\hline 1937 & 26,584 \\
\hline 1938 & 25,550 \\
\hline 1940 & 50,277 \\
\hline 1941 & 54,016 \\
\hline
\end{tabular}

Source: Ocherki istorii Kalininskoi organizatsii KPSS (M., Moskovskii rabochii, 1971), 690.

A first bulk of reproaches intersected with the judiciary repression going on simultaneously and brought the logic of the Great Terror to its close. ${ }^{53}$ Here, the purpose of the expulsions was to purify the Party of those who managed to disguise their true nature until the war but were eventually unmasked while they chose to work for the occupier. But many other Party members were expelled for a lot of reasons more symbolic than related to a concrete crime of treason. I shall successively examine these two sets of motives in order to assess the complex meaning of the purge.

\section{The Party purge followed the judiciary repression}

Historians of the Western postwar purges have underlined the intricate relation between the judiciary repression and the administrative, economic and social purges of those who brought disgrace on national honor. ${ }^{54}$ While new laws condemned ex post facto some kinds of behavior which were not illegal at the time they were adopted, extensive processes of cleansing developed in State and local administrations, enterprises, and in cultural and media circles. Sometimes, dismissals or reductions in rank were added to a judicial sentence, but not systematically. In other words, the "administrative" purge allowed society to purify itself deeper than justice alone could do.

Generally speaking, important forms of administrative and economic collaboration (functions of starshina, burgomaster, factory director, head of an economic department in the Municipality...) and espionage for the enemy were prosecuted by Soviet penal organs. They usually led to heavy sentences, from eight to ten years of detention in labor camps up to death penalty. In the Party, the punishment was expulsion, always accompanied by a dismissal from the job, be there or not judiciary prosecution. The Party's claim to embody the vanguard of society and to lead the people toward the Bolshevik goals logically resulted in the rejection of compromised communists. It was inconceivable to keep within the Party people whose loyalty turned out to be fragile.

Then, in the liberated USSR, a first group of expulsion criteria mostly tallied with the penal charges: blatant collaboration was at the core of it. Several ex-State officials, often chairmen of collective farms or of rural soviets, were thus expelled from the Party for administrative collaboration with the invader (reason (c), table 4). For instance, the previous chairman of Belogurovo soviet, in the Zubtsov district, was sanctioned for accepting the responsibility of starshina (head) of the Belogurovo county and starosta 
(elder) of the village. He eventually fled with the German troops when the Red Army came and freed the district. ${ }^{55}$ The conclusions of E. Beliaeva's case were more detailed: not only had she accepted to be a county starshina, but she had also scrupulously fulfilled her duty, sending regular accounts about the situation of the population, of the food stocks, and so on. She had even prepared a plan in order to gather 19 cows and deliver them to the Wehrmacht. ${ }^{56}$ In some cases, facts of administrative collaboration were aggravated by a charge of denunciation. A. Mironov, a 50-year-old collective farmer who joined the Party in 1931, confessed that he had accepted the function of starosta and interpreter of his village. One may suppose that he had been in German or Austrian captivity during the First World War, which would explain his language skills. The decision of expulsion stipulated that in addition, he had denounced Soviet partisans and soldiers to the enemy. ${ }^{57}$

Table 4. Causes of expulsion from the Party intersecting with penal charges, 1942-1945

\begin{tabular}{|c|c|c|c|c|c|c|c|c|}
\hline Cases examined by the Obkom & \multicolumn{2}{|c|}{1942} & \multicolumn{2}{|c|}{1943} & \multicolumn{2}{|c|}{1944} & \multicolumn{2}{|c|}{1945} \\
\hline $\begin{array}{l}\text { Cases related to behavior } \\
\text { during the invasion } \\
\text { or the occupation (A) }\end{array}$ & & 891 & & 351 & & 553 & & 229 \\
\hline $\begin{array}{l}\text { Number of expulsions } \\
\text { (and percentage in relation } \\
\text { to numbers under A above) }\end{array}$ & 1241 & $65.6 \%$ & 319 & $90.9 \%$ & 538 & $97.3 \%$ & 219 & $95.6 \%$ \\
\hline $\begin{array}{l}\text { Causes of expulsion (may be } \\
\text { involved concurrently) }\end{array}$ & & $n=1241$ & & $n=319$ & & $n=538$ & & $n=219$ \\
\hline $\begin{array}{l}\text { Non-authorized stay } \\
\text { in occupied territory (a) }\end{array}$ & 485 & $39.1 \%$ & 114 & $35.7 \%$ & 275 & $51.1 \%$ & 137 & $62.6 \%$ \\
\hline $\begin{array}{l}\text { Performance of various tasks } \\
\text { for the occupier or activity } \\
\text { during the occupation (b) }\end{array}$ & 581 & $46.8 \%$ & 155 & $48.6 \%$ & 168 & $31.2 \%$ & 64 & $29.2 \%$ \\
\hline $\begin{array}{l}\text { Position in the administrative } \\
\text { or economic structures } \\
\text { established by the occupier, } \\
\text { and/or espionage (c) }\end{array}$ & 107 & $8.6 \%$ & 76 & $23.8 \%$ & 54 & $10 \%$ & 18 & $8.2 \%$ \\
\hline $\begin{array}{l}\text { Displaying sympathy } \\
\text { for the occupier (d) }\end{array}$ & 52 & $4.2 \%$ & 15 & $4.7 \%$ & 8 & $1.5 \%$ & 4 & $1.8 \%$ \\
\hline $\begin{array}{l}\text { «Complicity» with a close } \\
\text { relative of friend } \\
\text { who collaborated (e) }\end{array}$ & 50 & $4 \%$ & 32 & $10 \%$ & 37 & $6.9 \%$ & 6 & $2.7 \%$ \\
\hline
\end{tabular}

Source: RGASPI, f.17, op.43, d.743-754; op.44, d.547-554; op.45, d.733-739.

32 Another frequent charge was economic collaboration, presented as voluntary or as aggravated by the consequences it led to. I. Zorin had both these criteria against him. Aged 24 when his district was invaded, he belonged to the generation of the young managers who received their education after the Revolution, and he joined the Party in 1940 , probably in relation to his appointment to the direction of Kunia linen factory. The regional conclusions about his expulsion stated that Zorin "had taken the path of betrayal" since the very first days of occupation and had himself suggested to the Germans to let him keep his position. ${ }^{58}$ Charges of collaborating by helping to repair damaged equipment, such as electric stations, factories, and so on, often appear in the expulsions for economic collaboration. ${ }^{59}$ 
whole, this first kind of expulsion (reason (c)) corresponds to the penal crime of holding official positions in the administrative or economic structures of the occupation regime. Another form of betrayal, not prosecuted before the tribunals, caught the attention of the Party committees: the "spontaneous" registration as a communist with the occupation administration or police. Actually, this act complied with official German orders: disobeying orders meant consciously risking one's life. But as registration prevented communists from leading any further underground activity, which was one of the prime duties of the activists, Soviet authorities considered it as an act of treason. Two situations were possible: either Party members spontaneously came to the German powers because they heard about the order and feared for their lives, ${ }^{60}$ or they complied with a summoning sent by the German kommandantur, and then confessed their membership, ${ }^{61}$ or even disavowed the Party. For instance, I. Belodedov was sanctioned for remaining in occupied territory without any authorization and for signing a renunciation of his Party membership after five days in a Gestapo jail. ${ }^{62}$

Another very frequent reproach was of being arrested, questioned and then released by the Germans. This was the case for a rural soviet chairman who survived after two summonings at the kommandantur and then worked on the construction of fortifications and the clearing of roads. ${ }^{63}$ In such cases, the Party committees suspected a deal: work, espionage or denunciation for survival. Once again, the purge criteria met those of the penal repression. For instance, E. Shliakova, who had been arrested by the German police on December 8, 1941, was afterwards accused of denouncing a comrade from the same factory (but his name and fate were not stipulated).$^{64}$ In 1943, Party rulings began to use the phrase "has been working for the Gestapo" and "has been in contact with the German police." ${ }^{65}$ This accusation often went along with the charge of denouncing Soviet patriots to the enemy. Sometimes, the spying activity, or at least a verbal commitment of that kind, was proven: the verified communists acknowledged they had signed a declaration binding them to identify Soviet partisans and activists. The case of $\mathrm{V}$. Sidorova, the young chair of a collective farm who was under arrest when the Party examined her membership, was no exception. ${ }^{66}$ However, according to the judiciary proceedings I was able to examine, in 1942 and even in 1943, this kind of incrimination was often used against the accused even when there was no proof in police records (of the death of the supposed victim, of interaction between the accused and the German forces, etc.). ${ }^{67}$

On the whole, the bulk of reasons similar to the penal repression represented approximately 8 to $10 \%$ of the total number of expulsions from the Party in 1942-1945, with a peak to $23 \%$ in 1943 . This suggests that the communists trapped in occupied territory most often tried to avoid blatant collaboration with the enemy. The statistics provided by J. Jones' study of the "reconstruction" in Rostov province point to a similar conclusion, except for the educational professions, where the rate of collaboration appeared to be high. ${ }^{68}$ The most frequent type of communist collaboration I observed in Party documents as well as proceeding records was the keeping of one's assignment as chairman of a collective farm (becoming starosta under the occupation) or as chairman of a rural soviet (becoming starshina under the Germans), and the registration as a communist with Nazi powers. In the latter case, registered communists had not systematically gone to work for the enemy.

The common features with the penal repression, at least at the beginning of the latter, encompass a second kind of behavior. First, the fact of fulfilling compulsory tasks 
imposed by the invader (reason (b), table 4): clearing the roads from snow, washing the soldiers' clothes, providing housing and food to the enemy... This also includes the performance of banal and unskilled activity in order to survive or sometimes to help one's fellow citizens. For example N. Grigor'ev, 56 years old, worked as a carpenter at the local hospital and also helped out at the mill. These duties seem all the more insignificant as Grigor'ev used to be a foreman at the Kalinin carriage factory, where he was specialized in machine repair: undoubtedly, a skill far more useful to the German army. ${ }^{69}$ The State Prosecutor's order of May 15, 1942 partly decriminalized this sort of activity, probably because it was usually compulsory, widespread and did not really hinder the Soviet war effort. ${ }^{70}$ But in the Party purge, this form of collaboration represented 46 to $49 \%$ of the causes of expulsion in 1942-1943. However, there was a change in favor of leniency during the summer of 1942. At the sessions of the Obkom bureau of August 5 and 12, for instance, several communists who had been expelled by their local committee for performing this kind of work were reinstated by the Obkom according to the logic of the order of May 15: the tasks accomplished by these people were declared "insignificant" and sometimes even "patriotic" (when they covered underground sabotage in favor of the Red Army or assistance to the local partisans). ${ }^{71}$ This pattern of expulsion decreased in the following years: $31.2 \%$ in $1944,29.2 \%$ in 1945 , most probably because of the legal reflections of 1942-1943 introducing greater nuances in the assessment of collaboration crimes..$^{72}$ The Party may also have experienced problems with a lack of cadres, which could partly explain the turn to leniency (in the case of low-level leaders). Moreover, it is very likely that the cases were quickly examined after each liberating offensive. Most of these communists obviously did not feel guilty before the Party, and they quickly came to their committee to be registered, ${ }^{73}$ which explains the predominance of this reason in the expulsion decisions of 1942 and 1943.

37 Frequenting the enemy or displaying sympathy to him also remind of some charges presented in the judiciary or extralegal repression (reason (d)). This group of people had not compromised themselves on a political or military level but they had betrayed their community on a symbolic level because they seemed to be delighted with the German presence. Moscow progressively defined a penal sanction, finally (in 1943) applying to them the notion of "socially dangerous elements" 74 widely used during the extralegal repressions of the 1930s. But the Party did not wait for that decision: as early as the beginning of 1942, two communists were expelled for this reason, and 32 more in the second term of the same year. ${ }^{75}$

Last, a last group of people was banned from the Party according to a logic reminding that of the resolution of the State Defense Committee of June 24, $1942 .{ }^{76}$ The members knew that their father, spouse or sibling had served the enemy and had hidden this fact afterwards (reason (e)). For example, the Party reproached M. Dorofeeva that she had not opposed her husband becoming the caretaker of building no. 86 in the Proletarskii worker city. ${ }^{77}$ E. Deviatkova was accused of not helping a partisan unit whereas she had been appointed head of its supplies. Moreover, she got close to a deserter from this unit, a "traitor and a German spy whom she hid at her house."78 This cause of expulsion never exceeded $10 \%$ of the whole amount of expulsions and was always associated with another reason, such as staying in occupied territory, or hiding a compromising relationship. Thus, even though A. Gromova had been promoted as chair of a rural soviet after the liberation, she was nonetheless excluded from the Party and dismissed from her job in 
October 1942, when the police discovered she kept a friendship with and protected a certain Gorbunova, former secretary of the collaborator Voronov. ${ }^{79}$

On the whole, the Party purge intersected with the criteria of the judiciary repression of traitors and collaborators, just going further in the punishment of collaboration crimes, punishing by expulsion acts that were not prosecuted by the court. ${ }^{80}$ In this respect, the purge was part of a global purification of society. But the process also used a second set of criteria which reminds of François Rouquet's conclusions on the postwar administrative purge in France: a large gap lay between the actual acts and their portrayal by the purging organs. This portrayal revealed the specific expectations of Party authorities toward their activists, in contrast to society as a whole. Party authorities had a highly politicized understanding of the petty facts of collaboration, whereas the deeds themselves were most often committed out of fear or hunger. ${ }^{81}$ In fact, the purge literally served the double purpose of regenerating society and redefining the values and norms of Party behavior. This portrayal revealed the specific expectations of Party authorities toward their activists, in contrast to society as a whole.

\section{The Party purge specificity: crime by omission}

Though they did not have a detailed picture of it, Soviet authorities knew of the main lines of the occupation regime even before the purge started. Some documents witness a high degree of awareness about the hard situation of the communists who were trapped in invaded territory. A note sent by Shamberg to the Central Committee secretaries in March 1943 underlined the bravery of many of them, provided examples of the different kinds of resistance and evoked the high number of executed heroes. Shamberg also admitted that the faltering communists had found themselves isolated after the invasion because of the failure of local Party committees which had not managed to organize underground cells beforehand, and afterwards did not send people to help the trapped comrades. The head of the Orginstruktotdel openly acknowledged that even the most active and determined communists had not been able to undertake any action in the absence of any direction. ${ }^{82}$

41 Anyway, the reproach of cowardice remained an almost irrefutable cause of exclusion from the start of the purge to its end. At the beginning, cowardice was identified with the loss or the destruction of the membership card during the invasion or the occupation (reason (b), table 5) ${ }^{83} \mathrm{~A}$ genuine paranoia had been attached to this topic since the prewar years, as illustrates Ivan Pyriev's film The Party Card (1935). A common idea was that a lost card could be used by a spy to learn some important information. ${ }^{84}$ But in reality, losing - or most often destroying - one's card had no impact on the conflict and could even appear as a clever move considering the tragic fate that awaited most communists and State officials if they were caught by the Nazis. ${ }^{85}$ Besides, the Soviet agents sent for special tasks in the enemy rear used to leave their membership card at the Obkom before leaving. Therefore, punishing someone for card loss was a purely symbolic measure: by destroying their Party document, members renounced the "noble name of communist" when they were confronted with danger. This symbolic gesture raised the question of how members adopted the communist identity and the whole ethos linked with it. Indeed, the Party had acquired the role of combative vanguard, driving force for the transformation of society - which justified its dominance over the 
people. This role implied rules of behavior that any member should be able to follow on a sole injunction of the hierarchy. ${ }^{86}$

Table 5. Causes of expulsion unrelated to penal prosecutions, 1942-1945

\begin{tabular}{|l|c|c|c|c|c|c|c|c|}
\hline & \multicolumn{2}{|c|}{1942} & \multicolumn{2}{c|}{1943} & \multicolumn{2}{c|}{1944} & \multicolumn{2}{c|}{1945} \\
\hline $\begin{array}{l}\text { Causes of expulsion (which } \\
\text { may be involved concurrently) }\end{array}$ & & $n=1241$ & & $n=319$ & & $n=538$ & & $n=219$ \\
\hline $\begin{array}{l}\text { Non-authorized stay } \\
\text { in occupied territory (a) }\end{array}$ & 485 & $39.1 \%$ & 114 & $35.7 \%$ & 275 & $51.1 \%$ & 137 & $62.6 \%$ \\
\hline Loss of membership card (b) & 449 & $36.2 \%$ & 57 & $17.9 \%$ & 228 & $42.4 \%$ & 95 & $43.4 \%$ \\
\hline
\end{tabular}

Source: RGASPI, f.17, op.43, d.743-754; op.44, d.547-554; op.45, d.733-739,

In the first year, this cause of expulsion appeared in $36.2 \%$ of the cases. This act was heavily sanctioned both by local and provincial committees, even when the communists in question had succeeded in escaping to free territory. For instance, the Obkom bureau cancelled the decision of Proletarskii district committee which had reinstated citizen Frolova in the Party because she had managed to reach Kashin: the final decision stated that she had destroyed her membership card during her flight. ${ }^{87}$ On the contrary, keeping one's Party document could protect the owner from the harshest sanction if other faults were committed. A. Esaulova, a young woman who had performed small tasks for the Germans, only received an official warning because she had kept her card. ${ }^{88}$ More surprisingly, some men also benefitted from such leniency, as I. Bavilkin, 46 years old, who could not flee when the invader came because of health problems. In this case, the man could rely on his 18-year experience in the Party, on the fact that he was still sick when the committee ruled on his case, and on the fact that he kept his card. ${ }^{89}$

Studying the evolution of the "cowardice" reproach allows us better to understand this mechanism. At the end of 1942, the reproach of refusing to fight in occupied territory succeeded that of losing one's card as the main symbol of cowardice. The notion of passivity in the hostile rear appeared in 1942 in decisions against men who stayed in invaded territory. T. Zhukov's case is exemplary. First, this 46 -year-old citizen was reinstated in the Party thanks to his good professional appraisal. Then the provincial committee cancelled this ruling, pointing to the fact that Zhukov had not evacuated and had destroyed his card, and adding that "he had not led any fight in the enemy rear." 90 This new accusation was always linked to the reproach of remaining in occupied territory, another main cause of expulsion. Indeed, this fact was always considered as resulting from choice and not accident. ${ }^{91}$ The phrase "did not try anything to evacuate while he (she) had the whole opportunity to do it" became a leitmotiv of expulsion decisions, making official the denial of a collective failure to organize and implement the evacuation. ${ }^{92}$ Women only - and not often - could be forgiven if they had children in their charge. On the opposite, men were almost always expelled, whatever be their past or present professional appraisal. A legless man in his sixties was thus expelled in 1943 because he did not manage to flee. ${ }^{93}$

These three criteria - card loss, passivity in the fight and "voluntary" stay in occupied territory - are essential to understand the meaning of the purge. They presuppose the absolute internalization of the communist ethos, denying the chaotic circumstances of evacuation and then occupation, and put forward the member's inability to act 
according to the implanted rules. This point really seems to differentiate this purge from the others, emphasizing more than ever the meaning of the individuals' acts, allowing to unmask "double-faced" individuals by using the method of "revelation by one's acts." 94 According to E. Cohn, after the Great Purges,

with only a few exceptions [...], the party never again sought to reshape its membership through mass purges or to use the party discipline system to stamp out the opposition or to unmask conspiracies against the Soviet state. Indeed, party documents proclaimed the need to judge misconduct by Communists on "an individual basis," guaranteeing (in principle) a careful examination of a Communist's behavior by a variety of party organs. ${ }^{95}$ new demand of individualization. The Party committees blamed communists who were suddenly cut off from their cell by the circumstances of the Nazi invasion for not making the good choice by themselves, without any order from the collective. After promoting for years the "Party discipline" and the collective spirit, the organization reproached its members for a lack of initiative in front of danger: they should have found the location of the partisan unit, imagined a way to cross the frontline or to sabotage enemy measures. Of course, the demand of initiative was in fact very limited, since in this picture, taking initiative complied with the supposedly natural behavior of a communist in this kind of situation. Nevertheless, the invasion and the reaction of the Party member 
actually constituted a test of the "communist conscience" of every activist: it revealed whether the last remains of bourgeois past had actually been crushed in the minds of the communists.

These unfulfilled expectations could explain the high rate of expulsion of freshly recruited members: in 1941, 50\% of Kalinin communists had been in the Party for less than three years. ${ }^{100}$ Sixteen out of 21 communists listed as collaborators by Toropets NKVD in April 1942 had joined the Party between 1939 and $1941 .{ }^{101}$ From this point of view, the purge fitted out in a Party routine consisting in a cleansing of the ranks after a large recruitment which had blurred the frontier between the vanguard and the rest of society. But now, the "good" member should know how to make true Stalin's summons of July 3, 1941 about "giving up carefreeness, mobilizing," "ignoring fear during the fight and selflessly going into the patriotic and liberating war against fascist slave drivers." 102 It was unthinkable and intolerable that the generation brought up after the Revolution could not "reveal themselves by their acts as worthy of the name of communist."

In early 1946, the local committee of Proletarskii district presented the outcome of the purge in the most affected district of the province (733 communists were expelled). The list of purged people illustrates this concern of differentiation according to individual situations, a concern that grew over time and levels of decision. ${ }^{103}$ The district committee adopted very different decisions towards people of the same category: the case of those members who tried to evacuate but chose the wrong direction and ended up in occupied territory is the most telling. Ten of them were reinstated without any punishment, 73 received an official warning and 244 were expelled from the Party. ${ }^{104}$ The category of communists who failed to escape because they suffered health diseases or were in charge of elderly infirm relatives usually enjoyed a certain leniency from the committee: 32 out of 66 were reinstated, and seven did not even receive any warning. As far as the provincial committee is concerned, its rulings show an actual will of differentiation, attenuating the sanction of four members who were either sick in 1941, or in charge of a family, whereas the local committee, as I pointed out, had already spared this category. But, on the contrary, the Obkom aggravated the punishment of six other representatives of this same group. Even more striking: the provincial committee mitigated the fate of 26 communists who tried to flee but did not succeed, and hardened the sanction of seven others. Last, it followed a very individual approach in dealing with the category of communists who remained in occupied territory "without any valid reason": whereas the raikom had pronounced 245 expulsions and 18 warnings, the Obkom ratified 214 decisions, attenuated 21 , hardened seven and decided that eight people did not deserve any sanction.

51 What can explain these differences inside the same category of behavior? Age does not seem to play a significant role. On the whole, the age structure of the 733 members who remained in occupied territory conforms to the age structure of the Party itself: a majority of potentially working adults ( 459 persons between 26 and 49), a sizeable part of people of the older generation (266 persons over 50) and a low number of young people (eight were less than 25). According to the purge decisions, the youth mostly tried to escape from the enemy while more representatives of the two other categories stayed in invaded territory "without any valid reason."

52 The gender distribution of the group is more telling: it corresponds to a society at war, where men are serving on the front. Women constitute $75 \%$ of the communists who had remained in occupied territory; as for the men, they were almost always sanctioned with 
greater severity. On one hand, the authorities expected that they resisted to the enemy. On the other hand, men seldom had the charge of the elderly and young children: they therefore could hardly justify their presence in invaded territory. A same bureau session could thus show both adamant severity and concern in case differentiation. For example, at the Obkom bureau session of May 20,1942, a 27-year-old woman escaped punishment, despite her failure to evacuate and the loss of her card, because she had a good Party appraisal and was responsible of two young children at the moment of invasion. ${ }^{105}$ Several other women who had tried to flee and destroyed their card were forgiven. But $\mathrm{T}$. Zhukov, a 46-year-old man punished by an official warning by his district committee, was expelled by the provincial committee just because he lost his membership card and stayed in his village during the occupation. ${ }^{106}$

53 A closer look at what the Obkom considered a "valid reason" reveals the flexibility of this notion. For example, V. Kashirina and I. Shitov were reinstated because the first one was considered too old to flee and the second one was sick when the Germans arrived. ${ }^{107}$ The committee cancelled an expulsion decision ruled against A. Usova, a 60-year-old doctor who was trapped in invaded Kalinin because she was waiting for a car in order to evacuate her patients from the town. ${ }^{108}$ During its session of December 17, 1942, the Obkom forgave a woman who cooked for the Germans and washed their laundry without even evoking the excuse of coercion; the decisive fact here seemed to be her excellent past professional appraisal. ${ }^{109}$ The Obkom forgave several similar cases during this session. On the contrary, the provincial committee expelled F. Dement'eva, 42 years old, because she came back in occupied Kalinin after the village where she fled had also been invaded and because she had lost her membership card. ${ }^{110}$

Beyond the main logics exposed above, some decisions remain obscure. For instance, why was 35-year-old Vladimir Usanov spared though he came back to Kalinin after the invasion of the village where he fled and did not lead any resistance activity? Neither the raikom nor the Obkom punished him. ${ }^{111}$ The same is true for $\mathrm{M}$. Ibragimov, 51, who was expelled by the local committee for the very same reasons, but reinstated by the provincial one in September 1942. One may assume these surprising outcomes had much to do with the lack of cadres after the liberation, as the example of Rostov much better illustrates. ${ }^{112}$

It often seems that enigmatic decisions, reinstatements or expulsions, were in fact based as much on the members' reactions to invasion and occupation as on their behavior since the liberation. The expulsion cases based on passivity in Party life since the liberation, which remind of the criteria of the second phase of the 1935 purge, ${ }^{113}$ appeared as early as 1942; they were often linked to a refusal to pay Party dues. Shortly after, another reproach emerged: not coming to the registration announced after the liberation. The decisions of expulsion labeled this attitude as "detachment from Party life." On the contrary, many reinstatement rulings were based on the general behavior of the communist towards work or militant activity. For instance, V. Burkina, 60 , was expelled by her raikom because she fled to a village that was invaded afterwards and because she could not retrieve her membership card - which she had hidden in a warehouse burnt by the enemy during their retreat. The city committee replaced the expulsion by an official warning, arguing that she really tried to escape and especially that she had excellent professional and militant appraisal. ${ }^{114}$ Similarly, M. Ivanova only received a warning even though she had destroyed her card and stayed in invaded territory; she had attempted to flee but failed, probably because of her dependent relatives - an infant and 
elder parents. The Obkom bureau decision stated that she had earlier distinguished herself as an excellent commander of the civil antiaircraft defense. ${ }^{115}$

The overlapping of criteria produces the impression, growing with time, that the war purge allowed a comprehensive purge of Party ranks, based on an upward reappraisal of the demands concerning investment in the Bolshevik project, during the occupation and after the liberation. In Kalinin, the confusion of the criteria leading to sanctions sometimes went as far as to arouse Central Committee concern: in June 1944, the highest Party organ expressed surprise about the collective expulsion of about 20 skilled workers of the Proletarka plant. They were all long-standing Party members and did not stay in occupied territory; the reason of their expulsion was that they "got detached from the Party" during the war. But the Central Committee's inspector considered them as "reliable." 116 Thus, the more the purge went on, the more it followed the logic that E. Cohn identified in the postwar years:

Many seemingly trivial organizational questions took on great symbolic importance in the party discipline process [...] At the same time, any Communist accused of misconduct would be judged not only on the facts of the case, but on whether he was a conscientious Communist who paid his dues and went to meetings. ${ }^{117}$

\section{Conclusion}

57 For Party members, the Second World War was indeed the "Armageddon of Revolution"118: it revived original values of the good Bolshevik (fighting spirit and sense of sacrifice for the collective project) while confirming the new method of appraising Party members by scrutinizing their intimate conscience, supposedly revealed by their acts. At the same time, the ordeal did not only test communist pugnacity: more broadly, it questioned the devotion and sincerity toward the Party. This wider angle preserved some members despite their sojourn in occupied territory. But it deeply shook Party structures just when the latter were central to the restoration of control over society.

Truly speaking, the Party purge was not the biggest shock that the organization underwent during the war, in comparison with mobilization or evacuation. One may even suppose the organs in charge of the purge took these factors into account when they pronounced reinstatements in favor of equivocal cases. The accounts drawn up in 1948, when the purge was completed in the province, present a total of 2,016 expulsions out of 2,705 examined cases, that is to say $74.3 \%$. Furthermore, 340 out of the 393 decisions of replacing a lost card (about half the whole number of reinstatements) concerned communists who did not live on occupied territory. Another thirty files were not even examined by the provincial committee because the members had died since the new registration (22 of them) or because members were automatically retrieved from the lists since they did not come to being registered (8). ${ }^{119}$ Thus if we look only at the communists who remained in invaded territory, the expulsion rate raises to $85 \%$ of the 2,373 examined cases, which proves the severity of the purge.

59 But the significance of the purge impact did not rely as much on its scope as on the fact that the Party structures had lost a high number of activists on the front, during the occupation and the displacements provoked by the invasion. The provincial organization had 54,016 members at the beginning of 1941; at the end of the war, only 4,474 of these 54,016 remained, for a total number of 31,016 regional communists in June $1945 .{ }^{120}$ Undoubtedly, the expulsion of 2,000 valid members heavily weighed on the 
Party's ability to supervise society after the liberation. Indeed, whereas the purge developed in complete secrecy, the Party hierarchy constantly urged the local committees to foster new admissions. Yet this was a complicated task when the pool of recruitment in the war years was almost completely limited to people who stayed in occupied territory, therefore suspected of disloyalty.

\section{NOTES}

1. Amir Weiner, Making Sense of War: The Second World War and the Fate of the Bolshevik Revolution (Princeton, Oxford: Princeton University Press, 2001), 82.

2. Graeme J. Gill, The Rules of the Communist Party of the Soviet Union (Houndmills, London: The Macmillan Press Ltd, 1988), 40-42, 165-183. In his brilliant Ph.D. dissertation about Party discipline from 1945 to 1961, E. Cohn underlines a shift in the post-war period: whereas Party purges tended to be more sporadic and massive phenomena before the war, they became a regular, albeit less harsh, phenomenon after the war. He explains this evolution by a shift in the relative importance of the various goals of sanctions (punitive, exclusive, pedagogical...). See Edward D. Cohn, "Disciplining the Party: The Expulsion and Censure of Communists in the Post-War Soviet Union, 1945-1961," Ph.D. dissertation, University of Chicago, 2007, 56-57.

3. On the growth of the obsessive fear of a "fifth column" from the 1920s to the war, see the case of Chechnya, studied by Jeffrey Burds, "The Soviet War against 'Fifth Columnists': The Case of Chechnya, 1942-1944," Journal of Contemporary History, 42, 2 (2007): 267-314. As for the transformation of the image of the internal enemy (vnutrennii vrag), see François-Xavier Nérard, "Une image de l'étranger en URSS dans les années trente," Bulletin de l'Institut Pierre Renouvin, 6 (1998): 33-34 and Nicolas Werth, L'Ivrogne et la marchande de fleurs: Autopsie d'un meurtre de masse, 1937-1938 (P.: Taillandier, 2009), 17.

4. Oleg Kharkhordin, The Collective and the Individual in Russia: A Stud $y$ of Practices (Berkeley, Los Angeles, London: University of California Press, 1999), 164-182.

5. For more details on the difference between these purges, see Chapter 8 of my doctoral thesis: Vanessa Voisin, "L'épuration de guerre en URSS, à partir de l'exemple de la région de Kalinine (1941-1953) [The War Purges in Soviet Union: A Study Based on the Case of Kalinin Province, 1941-1953]," doctoral dissertation, université Paris 1, 2011.

6. For example, in his interesting chapter about the repression and purge of collaborators in Rostov, Jeffrey Jones does not clearly distinguish between the simple activists and the members of the Party occupying a position of management in State, economic or Party structures (p. $164 \mathrm{ff}$.). That way, he concludes to a relative leniency of the purge in general, a position I do not agree with: Jeffrey W. Jones, "'In my Opinion this is All a Fraud!': Concrete, Culture and Class in the 'Reconstruction' of Rostov-on-the-Don, 1943-1948," Ph.D. dissertation, University of North Carolina, 2000.

7. On the western purges, see Marc-Olivier Baruch, ed., Une poignée de misérables: L'épuration de la société française après la Seconde Guerre mondiale (P.: Fayard, 2003); István 
Deak, Jan T. Gross, Tony Judt, eds., The Politics of Retribution in Europe: World War II and its Aftermath (Princeton: Princeton University press, 2000); Luc Huyse, Steven Dhondt, La répression des collaborations, 1942-1952 (Bruxelles: CRISP, 1993); Peter Novick, L'Épuration française, 1944-1949 (P.: Éditions Balland, 1985); François Rouquet, L'Épuration dans l'administration française: Agents de l'État et collaboration ordinaire (P.: CNRS Éditions, 1993). On Soviet historiography, see, for example, Ocherki istorii Kalininskoi organizatsii KPSS (M.: Moskovskii rabochii, 1971).

8. Amir Weiner, Making Sense of War. See also A. Weiner, "The Making of a Dominant Myth: The Second World War and the Construction of Political Identities within the Soviet polity," The Russian Review, 55 (October 1996): 638-660.

9. Nathalie Moine, "Expérience de guerre, hiérarchie des victimes et justice sociale à la soviétique," Cahiers du Monde Russe, 49, 2-3 (avril-septembre 2008): 383-418; Olaf Mertelsmann, Aigi Rahi-Tamm, "Cleansing and compromise: The Estonian SSR in 1944-1945," ibid., 319-340; Valdis O. Lumans, Latvia in World War II (New York: Fordham University Press, 2006); Geoffrey Swain, Between Stalin and Hitler: Class war and Race war on the Dvina 1940-46 (London, New York: Routledge Curzon, 2004); Elena Zubkova, Pribaltika i Kreml': 1940-1953 (M.: Rosspen, 2008).

10. Rebecca Manley, To the Tashkent Station: Evacuation and survival in the Soviet Union at War (Ithaca, London: Cornell University Press, 2008). See also Chapters 1 and 9 of my doctoral dissertation (see note 5 above).

11. RGASPI (Rossiiskii gosudarstvennyi arhiv sotsial'no-politicheskoi istorii - Russian State Archive of Social and Political History), f. 17 (Central Committee), op. 88, 122.

12. I searched extensively in the op. 3 of fund 147 (Kalinin regional committee) and in the funds of three districts committees (Proletarskii, f. 158; Rzhev, F. 148 and Zubtsov, f. 422) in the TTsDNI, Tver' Center of Documents on Contemporary History.

13. Tverskie arkhivy $v$ gody Velikoi Otechestvennoi voiny, 1941-1945. K 60-letiiu osvobozhdeniia g. Kalinina, Arkhivnyi otdel administratsii Tverskoi oblasti, Tver', 2001, p. 54-55.

14. TTsDNI, f. 158, op. 1, d. 79, 1. 1-7: minutes of the 1st meeting of Proletarka Party organization, January 4, 1942.

15. See, for example, RGASPI, f. 17, op. 122, d. 20, 1. 126-129: report from the head of the political department of the 9th Army to the Orginstruktotdel of the Main Political Direction of the Red Army, March 19, 1942. J. Jones observed a similar situation in Rostov province. Right after the complete liberation of the province, the regional organization discussed about the fate of the members who remained in occupied territory: Jones, "'In my Opinion this is All a Fraud!," 166.

16. RGASPI, f. 17, op. 88, d. 172, 1. 4 (information from Tishchenko, Voronezh first secretary, to the Central Committee, January 23, 1943 and 1. 12-19 (Tishchenko's report to Shamberg, February 12, 1943); Vladimir N. Haustov, Vladimir P. Naumov, N.S. Plotnikova, Lubianka. Stalini NKVD-NKGB-GUK R "Smersh" (193 9- $m$ art 19 46) (M.: Izd. Materik, Mezhdunarodnyi Fond "Demokratiia," 2006), 364 (information from Rostov), 366 (Leningrad), 367-368 (Velikie Luki), 369-370 (republic of Kabardino-Balkariia); RGASPI, f. 17, op. 88, d. 597, 1. 179: communiqué to Shamberg, Storozhev, Ratner and Karasev about the XI plenum of Kursk provincial committee, September 7, 1943.

17. RGASPI, f. 17, op. 122, d. 20, 1. 75-76: Ratner's report to A. Andreev, G. Malenkov, A. Shcherbakov, January 11, 1942. 
18. Undoubtedly, the context of war aggravated this phenomenon, but in the postwar years, the highest Party authorities (notably the Party Control Committee) often blamed the local committees for not paying enough attention to the conduct of their members. Most interestingly, the PCC did not approve situations when the Party committees reacted only after the police had already arrested the communist, or after a court had sentenced him: see Cohn, Disciplining the Party, 109-110.

19. RGASPI, f. 17, op. 122, d. 20, 1. 96-97.

20. RGASPI, f. 17 , op. 43 , d. 743,1 . 132ob: sixth point of the minutes of the session of February 25, 1942.

21. RGASPI, f. 17, op. 88, d. 573, 1. 43-47: report to Andreev, Malenkov, and Shcherbakov of March 1, 1942.

22. Weiner, Making Sense of War, 97. The author underlines that the Ukrainian Party Central Committee exerted the same pressure on local committees from 1944 to 1946 (ibid., 90, 97-102).

23. RGASPI, f. 17, op. 122, d. 20, 1. 98.

24. RGASPI, f. 17, op. 88, d. 597, 1. 129: report from an official of the Central Committee Orginstruktotdel to his chief, August 11, 1943.

25. The frequency was established by a systematic analysis of the minutes of the regional bureau sessions devoted to the examination of communists' personal files: RGASPI f. 17, op. 43, d. 743-748 (1942); d. 749-754 (1943); op. 44, d. 547-554 (1944); op. 45, d. 733-739 (1945).

26. Weiner, Making Sense of War, 97-101, 122-126.

27. Kharkhordin, The Collective and the Individual in Russia, 164-167.

28. I systematically studied all the issues of Proletarkaia Pravda that were kept in the State Archive (most of them) and those of the Rzhevskaia Pravda which were published after the liberation of the district (the first issue was released in April 1943). I also looked at Soviet newspapers and journals, such as Izvestiia, Krasnaia Zvezda, Bol'shevik, Voina $i$ Rabochii Klass and finally at specific editions designed for the Party agitators: Bloknot agitatora, Sputnik agitatora. Amir Weiner noticed the same discretion in the province of Vinnitsa in 1944: Weiner, Making Sense of War, 87.

29. A. Bormotov, "V raione, osvobozhdënnom ot nemetskikh okkupantov," Partiinoe Stroitel'stvo, 8 (April 1942): 30.

30. TTsDNI, f. 147, op. 3, d. 402: this file contains several explanations of simple members who stayed on occupied territory (1. 148-150, 162-162ob, 175-176, 267-267ob, 303-304ob), and of officials fearing dismissal and expulsion for an improper behavior before the invasion or during the occupation. In this same file, one can find certificates written by the local authorities about communists under verification: 1. 259-259ob.

31. TTsDNI, f. 147, op. 3, d. 403, 1. 43-49: certificates from Holm's local filial of the NKVD, May 11, 1942.

32. According to a joint resolution of the Central Committee and the government: Cohn, Disciplining the Party, 106-107. For more on the relationship between Party sanction and judicial prosecution, see Juliette Cadiot, "La justice soviétique ordinaire et la poursuite pénale des membres du parti communiste (1945-1953), to be published in Jahrbücher für Geschichte Osteuropas in 2012. I am grateful to the author for handing me her manuscript.

33. TTsDNI, f. 147, op. 3, d. 2744, 1. 82: Central Committee resolution, November 30, 1943. In July 1942, the Central Committee Orginstruktotdel told the regional committees that 
the Party Statute did not bind them to let an excluded member attend the session where his fate was decided for good: RGASPI, f. 17, op. 122, d. 20, 1. 164 (Ratner's note to Malenkov, July 20,1942).

34. RGASPI, f. 17, op. 88, d. 573, 1. 47.

35. TTsDNI f. 148, op. 3, d. 19, 1. 10 (Obkom bureau session, June 10, 1942) and 1.12 (session of October 14, 1942).

36. At the Obkom bureau session of June 3, 1942, for instance, the communists who were under arrest represented a quarter of the files examined that day (RGASPI, f. 17, op. 43, d. $745,1.12-27 \mathrm{ob}$ ). The same was true for the session of June 10, 1942 (ibid., 1. 45ob-60). In October 1942, 6 out of 18 members verified by the regional committee were at the hands of the NKVD (TTsDNI, f. 422, op. 1, d. 234, 241 and f. 148, op. 3, d. 19).

37. See, for example, the cases of E.D. Shliakova and E.I. Zurba: RGASPI, f. 17, op. 43, d. $745,1.19$ and $1.250 b$.

38. RGASPI, f. 17, op. 122, d. 20, 1. 107-108ob: Krylov's report to Shamberg, April 18, 1942.

39. See note 19.

40. See map.

41. The Rostov figures are taken from RGASPI, f. 17, op. 122, d. 98, 1. 90-104 (report from the delegate of the Party Control Committee to Malenkov, October 9, 1945). According to J. Jones, however, there were critics at the regional level about the slow pace of the verification, which prevented the local activists from reestablishing primary cells. Nevertheless, by the end of 1943 most of the cases had been examined: Jones, "In my Opinion this is All a Fraud!," $168 ; 172-173$.

42. RGASPI, f. 17, op. 43, d. 744, 1. 52ob (Turginovo district, April 27, 1942); d. 747, 1. 2-2ob (Ploskosh district, August 19); TTsDNI, f. 147, op. 3, d. 402, 1.292 (Kirov district, May 9, 1942).

43. See, for instance TTsDNI, f. 147, op. 3, d. 403, 1. 19 (report from the head of Orginstruktotdel of Kalinin's city committee, March 1942), 1. 291 (report from the secretary of Kirov district, not before March 18, 1942).

44. Weiner, Making Sense of War, 107.

45. Ibid., 95.

46. RGASPI, f. 17, op. 88, d. 597, 1. 32 et 135-136 (notes of July 2 and August 14, 1943, Kursk), 1. 53-54 (note of July 12, 1943, Voronezh), 1. 285-86 (note of December 2, 1943, Orël) op. 122, d. 584, l. 12 (note of October 14, 1943, Voronezh), op. 122, d. 63, 1.9 (note of January 11, 1944, Kursk), 1. 10 (note of January 25, 1944, Tatarstan), 1. 43-45 (note of April 25, 1944, Stavropol), op. 88, d. 634, 1. 13-14 (note of May 9, 1944, Kharkov), and so on.

47. TTsDNI, f. 147, op. 3, d. 2744, 1. 79-90: Simanov's report to A.A. Andreev and I.P. Boitsov, November 24, 1945.

48. TTsDNI, f. 147, op. 3, d. 402, 1. 292: resolution taken by the bureau of Kirov district committee, May 91942.

49. RGASPI, f. 17, op. 122, d. 20, 1. 107-108ob: report from the Orginstruktotdel of the provincial committee to the Central Committee, April 18, 1942.

50. TTsDNI, f. 147, op. 3, d. 297, 1. 69-70: report on the Party purge in Turginovo district (April 1942). 
51. RGASPI, f. 17, op. 88, d. 116, 1. 39-40: report from the Orginstruktotdel of Voronezh provincial committee to Shamberg, received on March 15, 1942.

52. Conclusive report of A. Zhdanov at the XVIII Party congress in 1939, quoted in Kharkhordin, The Collective and the Individual in Russia, 86.

53. In 1934, after claiming there was no more opposed classes in the Soviet Union, Stalin recommended vigilance towards the enemies infiltrated into the most vital organizations of the country: "careerists, profiteers and bureaucratized elements," "morally degenerated" members, "double-faced men" (dvurushniki), and "alien elements." See Nicolas Werth, Les Procès de Moscou (Bruxelles: Editions Complexe, 1987), 117: quotation from the proceedings of the XVII Party Congress, 1934. The Party congress in February 1937 had unequivocally pointed out the new enemy, with a Party card in hand. The Great Purge of 1937-1938 had aimed, among other things, at cleansing the Party and the ruling circles from the people regarded as the less trustworthy on the eve of a war that seemed more and more likely to take place. The Nazi invasion put the convictions and loyalty of many communists to the test, and seemed to reveal the last inner enemies.

54. See note 7.

55. RGASPI, f. 17, op. 43, d. 751, 1. 3ob: the expulsion was ratified by the Obkom bureau on June 6, 1943.

56. RGASPI, f. 17, op. 43, d. 745, l. 110: the expulsion was ratified by the Obkom bureau on June 17, 1942.

57. Ibid., 1. 14: the expulsion was ratified by the Obkom bureau on June 3, 1942.

58. Ibid., 1. 14ob: minutes of the Obkom bureau session, June 3, 1942.

59. TTsDNI, f. 148, op. 3, d. 19, 1. 36 (mechanic of the Rzhev water tower, May 10, 1942), TTsDNI, f. 422, op. 1, d. 241, 1.9 (stock manager of Zubtsov's linen factory, November 18, 1942), RGASPI, f. 17, op. 3, d. 745, 1. 24 (workman appointed to reconstruction work at Kalinin's 3rd electric station, June 3, 1942), ibid., 1. 21ob (workman appointed to reconstruction work at Proletarskii weaving factory, June 3, 1942), etc.

60. Ratification of A. Shasetskin's expulsion, June 3, 1942 (RGASPI, f. 17, op. 43, d. 745, 1. 24), and of M. Baranov's expulsion, June 20, 1942 (TTsDNI, f. 148, op. 3, d. 19, 1. 99).

61. RGASPI, f. 17, op. 43, d. 745, 1. 22: ratification of A. Iakovleva's expulsion, June 3, 1942.

62. Ibid., 1. 25: ratification of I. Belodedov's expulsion, June 3, 1942.

63. RGASPI, f. 17, op. 43, d. 748, 1. 25: a 35-year-old man, whose expulsion was confirmed on October 28, 1942.

64. RGASPI, f. 17, op. 43, d. 745, 1. 19: the expulsion was ratified by the Obkom bureau on June 3, 1942.

65. RGASPI, f. 17, op. 43, d. 749, 1. 13: ratification of N. Boikov's expulsion, January 6, 1943. The man had been the chairman of a rural soviet; he was arrested by the NKVD before the Party studied his case.

66. TTsDNI, f. 148, op. 3, d. 19, 1. 37: the expulsion was ratified by the Obkom bureau on June 6, 1943.

67. As part of an overall study of war purges (dealing with the penal prosecution as well as the Party and administrative purges), I studied about 80 proceeding records of people condemned for collaboration in the province of Kalinin, mostly in 1942. These files are kept in the fund of the rehabilitated victims of Soviet political repressions (TTsDNI, f. 
7849), so it is not really surprising that the inquiry lacked serious evidence. What is more surprising is the fact that these individuals could have been condemned on the sole charge of administrative/economic collaboration, but the NKVD insisted on bringing up the accusation of denunciation.

68. Jones, “'In my Opinion this is All a Fraud!," 170-171.

69. RGASPI, f. 17 , op. 43 , d. $745,1.20$ ob: the expulsion was ratified by the Obkom on June 3 , 1942.

70. Sbornik zakonodatel'nykh $i$ normativnykh aktov o repressiiakh $i$ reabilitatsii zhertv politicheskikh repressii (M.: Izd-vo "Respublika", 1993), 39-41.

71. RGASPI, f. 17, op. 43, d. 746, l. 123-146 (Obkom bureau session of August 5, 1942) and l. 161-189 (session of August 12, 1942).

72. See Sergey Kudriashov, Vanessa Voisin, “The early stages of 'legal purges' in Soviet Russia, 1941-1945," Cahiers du Monde Russe, 49, 2-3 (avril-septembre 2008): 263-296.

73. Significantly, hiding one's sojourn in occupied territory became a frequent criterium for expulsion starting in 1944.

74. In April 1943, the Special Conference of the NKVD received the right of punishing as "socially dangerous elements" (art. 35 of the 1926 Penal Code of the RSFSR) "the Soviet citizens who, not being at German service, had willingly kept private relationships, either intimate or friendly, with the occupation troops or with the officials of administrative or repressive fascist organs if any information indicates that these individuals could be used by the enemy because of these relationships": V.V. Obukhov, "Pravovye osnovy organizatsii i deiatel'nosti voennykh tribunalov voisk NKVD SSSR v gody Velikoi Otechestvennoi voiny 1941-1945 gg.," doctoral dissertation, MVD Academy, M., 2002, 120-121.

75. RGASPI f. 17 , op. 43 , d. 743-748.

76. This resolution imposed the relegation for five years of the adult close relatives of a traitor sentenced to death, with the exception of the families including a partisan or a soldier serving in the Soviet armed forces. In April 1943, an order jointly signed by the People's commissars of Justice and of Internal Affairs and the State Prosecutor of the USSR ordered the police and judiciary organs to intensify the repression of acts of treason as well as close relatives of traitors. We must here underline that the Party showed greater severity than Soviet law: relatives of any kind of traitor (was the latter sentenced to death or not) were liable to expulsion.

77. RGASPI, f. 17 , op. 43 , d. 745,1 . 19: the expulsion was ratified by the Obkom bureau on June 3, 1942.

78. Ibid., 1. 15: the expulsion was ratified by the Obkom bureau on June 3, 1942.

79. TTsDNI, f. 148, op. 3, d. 19, 1. 18: excerpt from the minutes of the session of the Obkom bureau, October 14, 1942.

80. That is, when they chose the punishment - the harshest one even for petty forms of collaboration; of course, it is hard to compare the fact of being expelled from the Party with detention in labor camp or even the death penalty.

81. Rouquet, L'Épuration dans l'administration française.

82. RGASPI, f. 17 , op. 88 , d. 595, 1. 33-34: Shamberg's note to the Central Committee, March 1943.

83. See also Jones, “'In my Opinion this is All a Fraud!," 172-173. 
84. Cohn, Disciplining the Party, $60-61$.

85. The specific policies adopted by the Nazi invaders towards the members of the Party are exposed in monographs on occupation in Soviet territory. For a synthetic overview, see Dieter Pohl, Die Herrschaft der Wehrmacht: deutsche Militärbesatzung und einheimische Bevölkerung in der Sowjetunion 1941-1944 (Munich: R. Oldenbourg Verlag, 2008). Moscow was quickly informed of the fate that awaited several categories of Soviet citizens under Nazi rule (the Jews, the communists and State officials). Alexander Werth, who covered the events of the eastern front for the Sunday Times and the BBC, recalls that everybody knew the risks incurred by Party officials but the hierarchy nonetheless commanded them to stay at their post until they were told otherwise: Alexander Werth, La Russie en guerre, 1941-1944 (P.: Tallandier, 2010), t. 1, 384.

86. Dietrich Beyrau, "The Bolshevik Project as a Plan and Social Practice," Ab Imperio, 3 (2002): 367. The author underlines that many of these rules of behavior existed in the Party even before the October Revolution. But it was under Stalin that the "Party discipline" progressively replaced the sole marxist ideology as a driving force to action (364).

87. RGASPI, f. 17, op. 122, d. 20, 1. 108: report from the provincial Orginstruktotdel, April 18, 1942.

88. TTsDNI, f. 422, op. 1, d. 234, 1. 35: minutes of the session of Zubtsov raikom bureau, October 10, 1942.

89. TTsDNI, f. 422, op. 1, d. 234, 1. 30ob: minutes of the session of Zubtsov raikom bureau, October 3, 1942.

90. TTsDNI, f. 147, op. 3, d. 300, 1. 108-109: session of the Obkom bureau of May 20, 1942.

91. V. Voisin, "Les individus demeurés en territoire occupé: aspects singuliers de l'épuration soviétique, 1942-1949," Revue d'Études Comparatives Est-Ouest, (2006): 198-236.

92. See Manley (R.), To the Tashkent Station and Voisin, "Les individus demeurés en territoire occupé..."

93. TTsDNI, f. 158, op. 1, d. 160, 1. 12: list of the purged communists in Proletarskii district (Kalinin), January 7, 1946.

94. The expression is borrowed to Oleg Kharkhordin: it means studying in details the acts and thoughts of the communist.

95. Cohn, Disciplining the Party, 54.

96. RGASPI, f. 17 , op. 43, d. $743,1.132 \mathrm{ob}: 6^{\text {th }}$ point of the minutes of the session of the Obkom bureau, February 25, 1942.

97. RGASPI, f. 17, op. 88, d. 116, 1. 39-40: Pisenkevich's report to Shamberg, March 15, 1942.

98. Beyrau, "The Bolshevik Project as a Plan and Social Practice," 360-361, 366-368.

99. Kharkhordin, The Collective and the Individual in Russia, 164, 182-183.

100. Ocherki istorii Kalininskoi organizacii, 690.

101. TTsDNI, f. 147, op. 3, d. 108, 1. 49-52. All of them were expelled from the Party.

102. E.N. Kul'kov, M.Iu. Miakhkov, O.A. Rzheshevskii, Voina 1941-1945 (M.: Olma-Press, 2001), 351.

103. TTsDNI, f. 158 , op. 1, d. 60 . The 1946 document draws a picture of the purge in Proletarskii district starting in 1942. 
104. On the hierarchy of Party sanctions and the frequent arbitrariness of the choice between them, see Cohn, Disciplining the Party, 64-68.

105. TTsDNI, f. 147, op. 3, d. 300, l. 143: minutes of the session of the Obkom bureau, May $20,1942$.

106. Ibid., 1. 109.

107. RGASPI, f. 17, op. 122, d. 20, 1. 107ob: report from Kalinin Orginstruktotdel to the Central Committee, April 18, 1942.

108. TTsDNI, f. 147, op. 3, d. 300, 1. 139: minutes of the session of the Obkom bureau, May $20,1942$.

109. RGASPI, f. 17 , op. 43 , d. $748,1.242: 36^{\text {th }}$ of the minutes. The used phrase is "Kak proizvodstvennitsu i kak obshchestvenniku RK VKP(b) kharakterizuet t. Trunovu s polozhitel'noi storony."

110. RGASPI, f. 147, op. 43, d. 745, 1. 20: minutes of the session of the Obkom bureau, June 3, 1942.

111. TTsDNI, f. 158, op. 1, d. 160, 1. 4ob: list of the verified communists in Proletarskii district, January 7, 1946.

112. Jones, "In my Opinion this is All a Fraud!," 164 and 168-172. Unfortunately, this very good study does not clearly differentiate the fate of the cadres from that of the Party members in general. In Kalinin, the treatment was very different when the purge touched upon people necessary to relaunch economic activity (be there in the Party or not) and the Party organization in general (be the members cadres or not). For details on this difference, see my dissertation: "L'épuration de guerre en URSS...," chap. 8.

113. Gabor T. Rittersporn, Simplifications staliniennes et complications soviétiques: Tensions sociales et conflits politiques en URSS, 1933-1953 (P.: Editions des Archives Contemporaines, 1991), 91-92.

114. TTsDNI, f. 147, op. 3, d. 300, 1. 110: minutes of the Obkom bureau session, May 20, 1942.

115. TTsDNI, f. 147, op. 3, d. 297, 1. 116ob: minutes of the Obkom bureau session, April 29, 1942.

116. RGASPI, f. 17, op. 88, d. 634, 1. 68: report from the Central Committee Orginstruktotdel, June 3, 1944.

117. Cohn, Disciplining the Party, 61.

118. The phrase is taken from Weiner, Making Sense of War, 17.

119. TTsDNI, f. 147, op. 4, d. 497, l. 115: data on July $1^{\text {st }}, 1948$.

120. Ocherki istorii Kalininskoi organizatsii, 690,508 . The 25,000 lost members probably died during the war, left the region or were expelled from the Party.

\section{ABSTRACTS}

Abstract

The article tries to seize the role of the Second World War in the evolution of the criteria that 
defined the good communist. This evolution completed a shift initiated in the 1930s from genealogical criteria (social origin, political past...) to criteria focused on the communist's inner "self." First, the author examines the launching and mechanisms of the purge from 1942 to the immediate postwar years, at the national level as well as that of a region whose liberation started early in the war. For Moscow, the purge was a top priority despite the lack of activists in liberated territory. However, there was some misunderstanding between the various levels of authority about the criteria of censure, expulsion or reinstatement. The second part of the article examines these criteria and their meaning in the history of Soviet Party purges. Some communists were punished for the same motives that triggered judicial prosecution, whereas others were heavily censured although their acts were not considered as crimes in the penal system. The deep meaning of the purge lies in this second set of criteria: for Party members, the Second World War was indeed the "Armageddon of Revolution" (A. Weiner). It revived the original values of the good Bolshevik (fighting spirit and sense of sacrifice for the collective project) while confirming the new method of appraising Party members by scrutinizing their intimate conscience, supposedly revealed by their acts. At the same time, the ordeal did not only test communist pugnacity: more broadly, it questioned sincerity and devotion to the Party. This broader viewpoint preserved some members despite their sojourn in occupied territory. However, it deeply shook Party structures just when the latter were central to the restoration of control over society.

Résumé

L'article tâche d'apprécier le rôle de la Seconde Guerre mondiale dans l'évolution des critères définissant le bon membre du parti, dans le prolongement d'un glissement, initié durant les années 1930, de critères généalogiques (origine sociale, passé politique...) vers des critères centrés sur le «soi » intime de l'individu. Tout d'abord, le texte étudie le lancement et le fonctionnement de la purge, de 1942 à l'immédiat après-guerre, tant à l'échelle soviétique qu'à celle d'une région dont la libération débuta précocement. Pour Moscou, l'épuration constituait une priorité essentielle, en dépit de la pénurie de militants dans les zones libérées. On observe cependant une certaine confusion entre les différents niveaux d'autorité quant aux critères de sanction, d'expulsion ou de maintien. La seconde partie de l'article se penche sur les critères eux-mêmes et leur signification dans l'histoire des purges du parti bolchevik. Certains communistes furent punis pour des raisons similaires à celles qui suscitaient au même moment des poursuites judiciaires, tandis que d'autres furent lourdement sanctionnés malgré l'absence de crime (au sens pénal) dans leurs agissements. Le sens profond de la purge repose dans ce second ensemble de motifs de sanction : pour les membres du parti, le second conflit mondial fut bien «l'Armageddon de la Révolution » (A. Weiner). Il ranima les valeurs originelles du bon bolchevik (esprit combatif et sens du sacrifice personnel au nom du projet collectif) tout en enracinant le recours à la nouvelle méthode d'évaluation des membres du parti: l'examen de leur conscience intime, supposée se révéler dans leurs actes. En même temps, la guerre ne testa pas uniquement la pugnacité des militants: plus généralement, elle mit à l'épreuve leur dévouement et leur sincérité à l'égard du parti. Cet angle de vue plus large permit à certains communistes restés en territoire occupé de ne pas être épurés. Néanmoins, la purge ébranla profondément les structures partisanes alors même que celles-ci étaient essentielles au rétablissement du contrôle du parti sur la société.

\section{AUTHOR}

\section{VANESSA VOISIN}

CEFR, Moscou / IRICE, Paris 